\title{
Design Information System Accounting Sales Website-Based (Case Study: PT Arbunco Wira Pandega)
}

\author{
Janu Ilham Saputro ${ }^{1}$, Nadia Khaerun Nissa ${ }^{2}$, Nadia Yulandha ${ }^{3}$ \\ ${ }^{1,2,3}$ Raharja University, Jl. Jendral Sudirman No.40 Modern Cikokol Tangerang \\ e-mail: januilham@gmail.com, nadia.khaerunnissa@raharja.info, nadia.yulandha@raharja.info
}

To cite this document:

Saputro, J., Nissa, N., \& Yulandha, N. (2020). Design Information System Accounting Sales WebsiteBased (Case Study: PT. Arbunco Wira Pandega). Aptisi Transactions on Management (ATM), 4(2), 158-168.

DOI:

https://doi.org/10.33050/atm.v4i2.1263

\begin{abstract}
PT. Arbunco Wira Pandega does not have a system that covers all activities, one of which is in the sales department and the financial section in making sales reports and financial reports are still manually using Microsoft. Excel so that the media used are still very likely to cause human error so a sales accounting system is needed so that it can produce sales reports and financial reports that are more effective and efficient in the process of making sales reports and financial reports. This research uses the SWOT analysis method, PIECES, system requirements elicitation, and system modeling using UML (Unified Modeling Language) to visualize, which is then implemented with the Hypertext Preprocessor (PHP) programming language with the MySQL-Server database as the database used. With the sales accounting system, it can simplify the sales department and the finance department to produce accurate sales and financial reports in a fast time, so as to create effective and efficient performance, and can support evaluation in internal control for the leadership of the report.
\end{abstract}

Keywords: Sales Report, Accounting, Sales Accounting System

\section{Introduction}

The transaction process at PT. Arbunco Wira Pandega requires a system that makes it easy to manage information that results in the form of sales reports and financial reports. Finance in any company must be considered as well as at PT. Arbunco Wira Pandega finance must be managed properly. In the company PT. Arbunco Wira Pandega, every transaction that is currently running is using a computer, but the processing is still using a manual system and not using an information system.

Therefore the accounting department and the Sales department need a long time in copying data on report paper and after that have to be typed back on a computer machine using Microsoft Office software (Microsoft Excel). the process is still less effective if seen enough transactions done by the company.

For example, the sales department must write on the customer's name paper, type of service, transaction date and payment date must also be written in full according to information on the transaction then must be recapitulated into Microsoft Excel. 


\section{Research Method}

The research method of PT Arbunco Wira Pandega is used to solve various problems that exist in this research. The data collection methods used, among others :

1. Observation Research

Data collection by observing directly on PT. Arbunco Wira Pandega, located on Jl. Gatot Subroto Kav 21 RT 003 RW 002 Karet Semangi, Setiabudi, South Jakarta. To request the data needed by researchers in making the system.

2. Interview Research

The method used to obtain data by visiting sources directly related to the sales department and the accounting department will be examined by oral delivery.

3. Library Research

The method used to obtain information from several sources of literature such as books, journals, papers, internet, and so on relating to research as reference material in preparing reports.

The following is a list of literature reviews used in this study :

1. Research in a journal conducted by Maimunah, et al (2016), from STMIK Raharja, entitled "IMPROVING THE PERFORMANCE OF SALES ADMINISTRATION OF CHEMICAL WATER TREATMENT PRODUCTS WITH THE UTILIZATION OF INFORMATION SYSTEMS". The advantage is that this research can design a sales administration information system program that facilitates the coordination of sales administration of water treatment chemical products. In this study using MySQL for database management which can store all sales reports and present accurate data, and produce timely reports in accordance with the desired needs.

2. Research in a journal conducted by Sandro Alfeno and Wury (2018), from STMIK Raharja, entitled "ANDROID HYBRID-BASED MOBILE COMMERCE (MCOMMERCE) APPLICATION". The advantage is that this research can create an Android Hybrid-based Mobile-Commerce Application using web programming language and can be applied in a mobile platform to facilitate the marketing department in advertising its products as well as facilitate in making sales reports and facilitate customers in knowing what products are available. sold as well as in buying and selling transactions The system development method used in making this MCommerce application is the SDLC (System Development Life Cycle) method with the Waterfall model.

3. Research in an international journal conducted by Mohammad Shadiq and Zaki Baridwan (2015), from Brawijaya University entitled "An Empirical Study on Organizational Acceptance Accounting Information Systems in Sharia Banking". This study aims to determine the role of external variables, including management support and self-efficacy of variables that affect the perceived usefulness and perceived ease of use of Islamic Banking Accounting Information Systems (AIS). Research in a journal conducted by Aris, et al (2017), entitled "Application of Motorcycle Spare Parts Sales System at Web-Based Barokah Motorcycle Workshop". The advantage is that with this research can build a system that can speed up the performance of the administration in processing data, because the administration only has to enter what data items are purchased by the customer. Easy in making reports, because transaction data is automatically saved so the administration only needs to select the sales report period to be printed. Data is maintained, because the sales system that is designed already uses a database. Easy to use, because it is designed with a simple user interface using the PHP programming language. Users no longer need to record every transaction and manually recap data, because the system is made according to existing requirements. Users only search for the name of items purchased and enter the purchase quantity on the transaction menu. While on the report menu, the user only has to select the period of the month that they want to print / display. The system was designed using the OOAD method, and 
illustrated through UML diagrams such as activity diagrams, sequence diagrams, use case diagrams, class diagrams and state chart diagrams.

4. Research in a journal conducted by Rika Kharlina (2017), from STIE Multi Data Palembang, entitled "Analysis and Design of Sales and Inventory Accounting Information Systems at PT XYZ". The advantage is that the existence of this research can design a system so that existing records can be more easily grouped and searched if needed and provide convenience in terms of presenting accounting reports from recording data that has been done and stored in a database. The drawback is that the design of the display that is displayed in the journal is still in the form of a prototype. The research methodology used in this study is a qualitative research approach. A qualitative approach is used to describe the analysis of conditions and procedures that are running at PT. XYZ and to design accounting information systems, not lead to the processing of statistical data in the company.

\section{Results and Analysis}

\subsection{Problem Analysis}

Based on the analysis done, there are several problems encountered among them:

1. Based on the analysis conducted by researchers, the sales system and the accounting system that are running have used semi-computerization, but the existing system has not been integrated and part of the process is still done manually, so that data processing has not been obtained quickly, precisely, and accurately and the system that is running cannot implemented efficiently and effectively.

2. Research problems faced in a system that runs in recording sales transactions and recording Financial accounting still uses Microsoft Excel, with a recording system like this there are many shortcomings such as more time consuming because the reports generated are not automatic or manual and it results in delays in report data sales from the sales department and financial statement data from the accounting department that affect the delay in information to the leadership needed for decision making, and result in unmatched losses such as increased operational costs.

\subsection{Troubleshooter}

Based on the analysis of the current system, conclusions, shortcomings and needs of the stakeholders can be made, the development of the system should be carried out, and namely, analyzing these needs can be taken several alternative solutions to problems, among others:

1. Creating a system that is needed by the user by using visual-based applications because visual-based applications are familiar among the public agencies.

2. Creating a web-based system application, an application built based on the web allows users to use data together at the same time. 


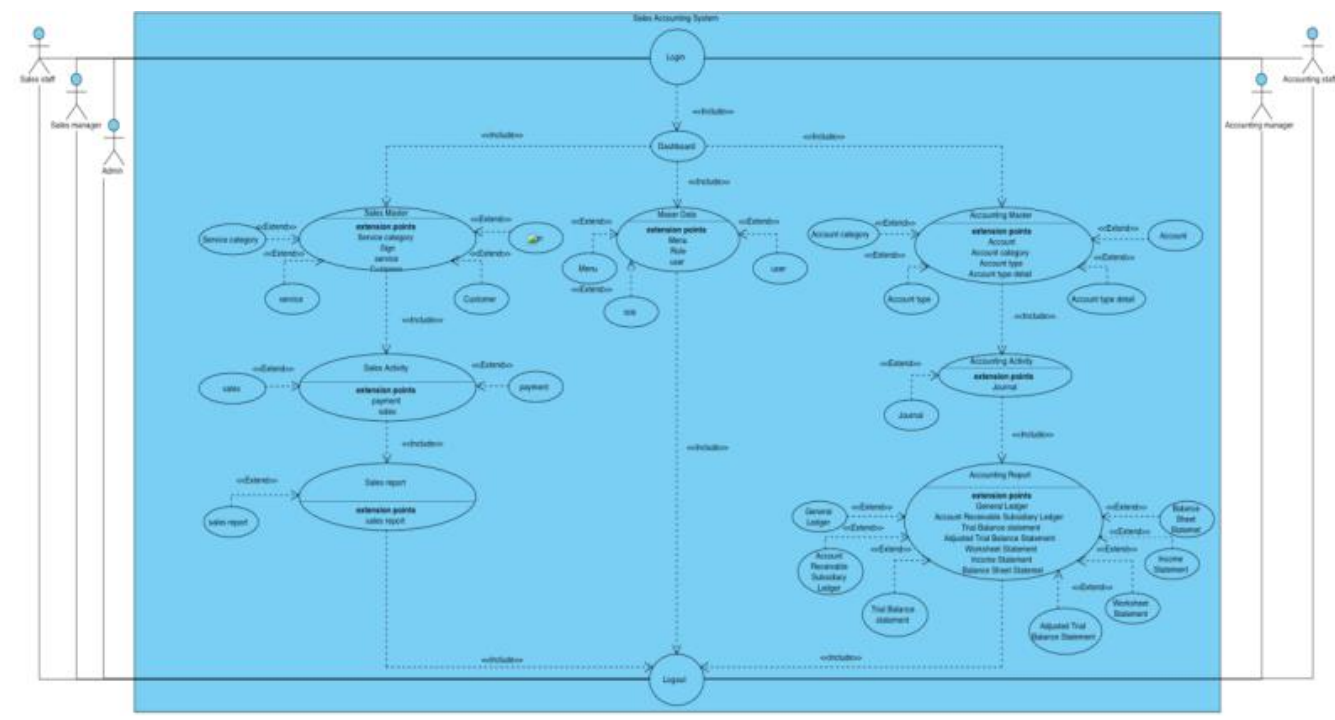

Figure 1. Use Case Proposed System Diagram

\subsection{Implemantation}

The following is an overview of the interface display of sales accounting information systems can be seen in the following figure:

\section{Page Display Login}

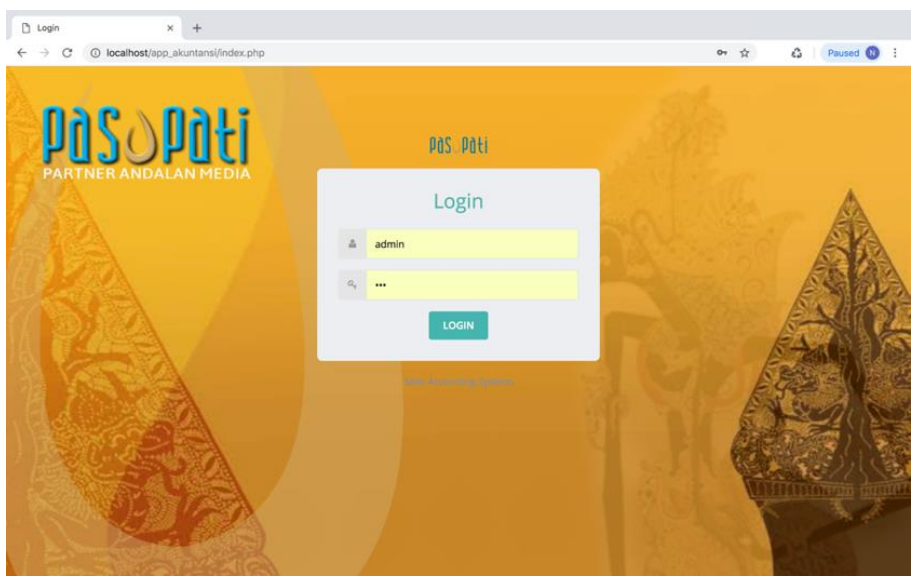

Figure 2. Page Display Login

The above display is the initial display before entering the system, each user must log in by entering the correct username and password in order to enter the system. 


\section{Page Display Add Role}

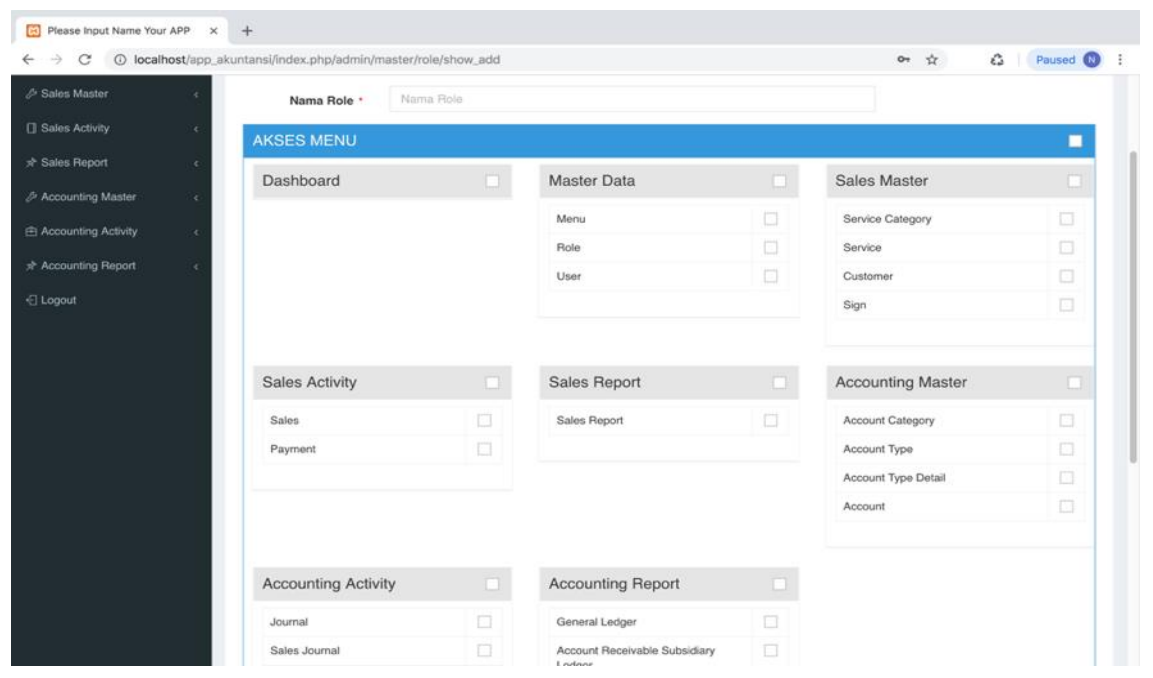

Figure 3. Display Dashboard

The above display is a form display to filter user access rights.

\section{Display Page Menu Account Type Details}

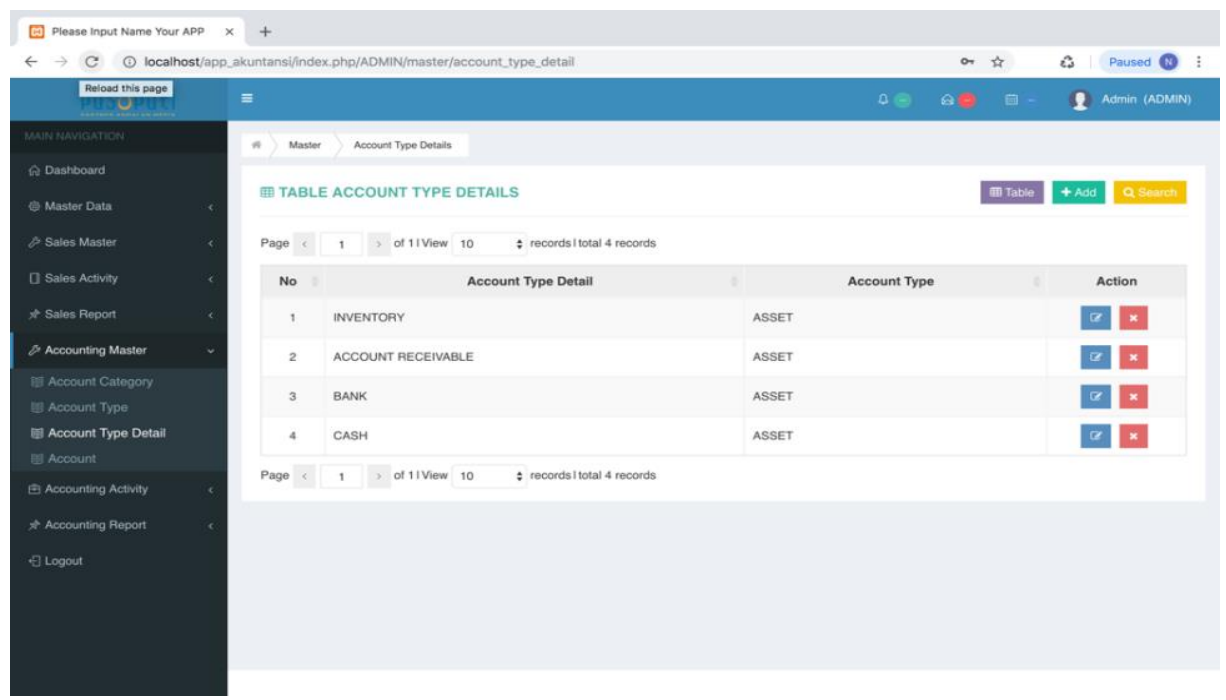

Figure 4. Page Display Area Data

The above display is a view of the Account Type Detail menu page which presents a page in which there is data that has been inputted into Account Type Detail data. On this page, users can add data, edit data, delete data and search data. 


\section{Display Page Menu Account}

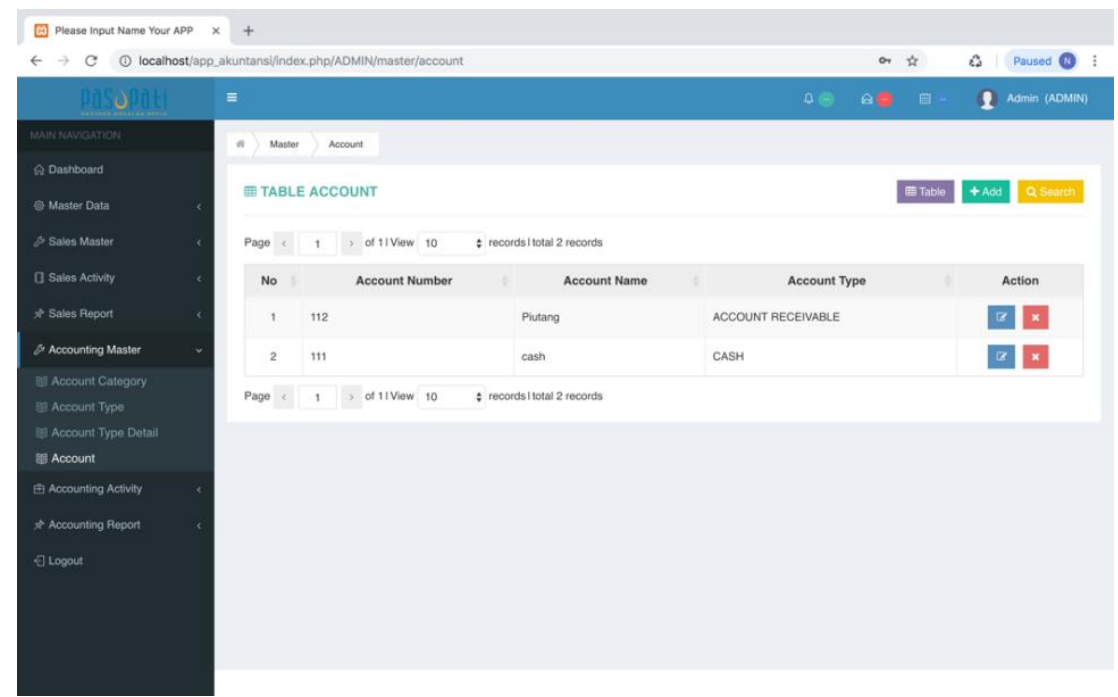

Figure 5. Display Page Menu Account

The above display is a view of the Account menu page which presents a page where there is data that has been inputted into the Account data. On this page, users can add data, edit data, delete data and search data.

\section{Journal Data Input Page Display}

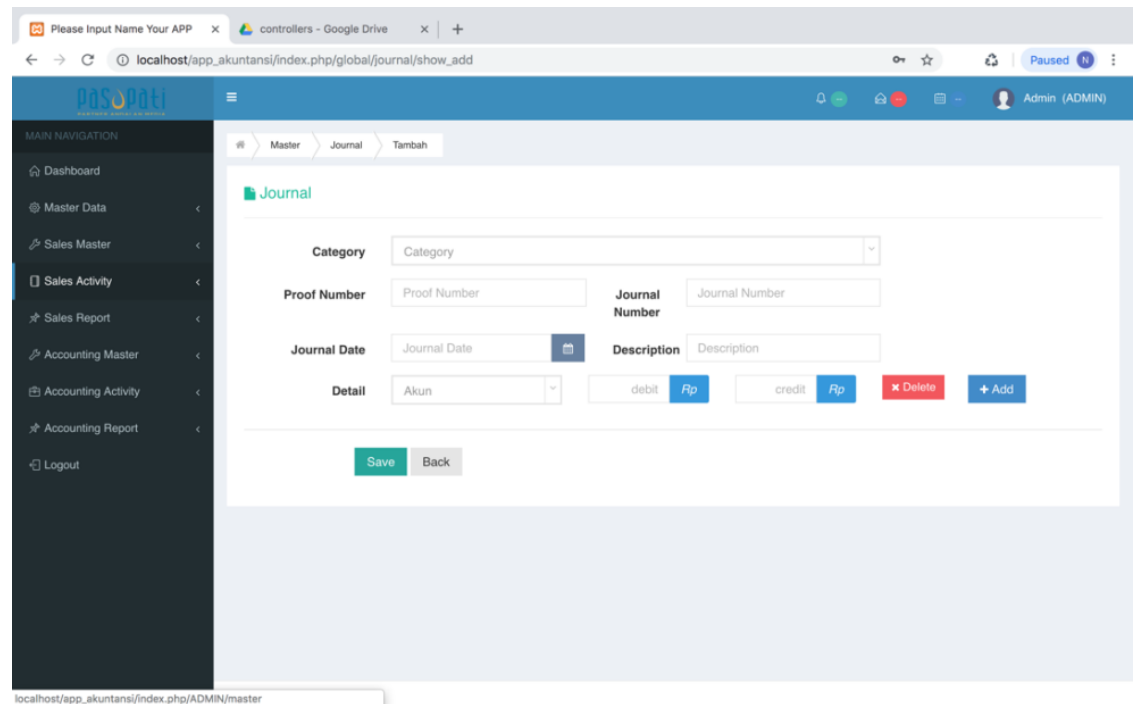

Figure 6. Journal data input page display

The above display is a form display for inputting Customer data where users can fill in Categories, inv.date, due dates, customers, invoice number, up., SO / PO Reff, sign, service and quantity. Furthermore, if all data is filled, it will be stored. 


\section{Display Page Journal Menu}

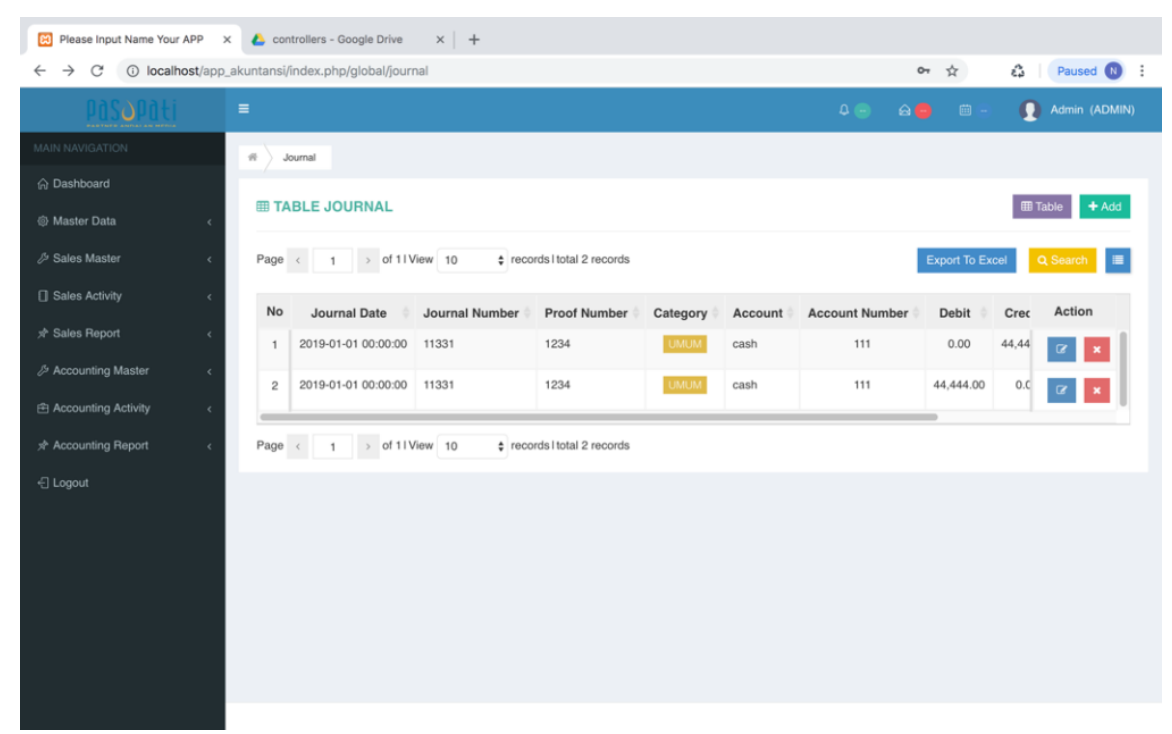

Figure 7. Display Page Journal Menu

The above display is a view of the journal menu page which presents a page in which there is data that has been inputted in the journal data. On this page, users can add data, add mandatory savings, edit, delete, search and print data export to excel.

\section{Display Page Service Menu}

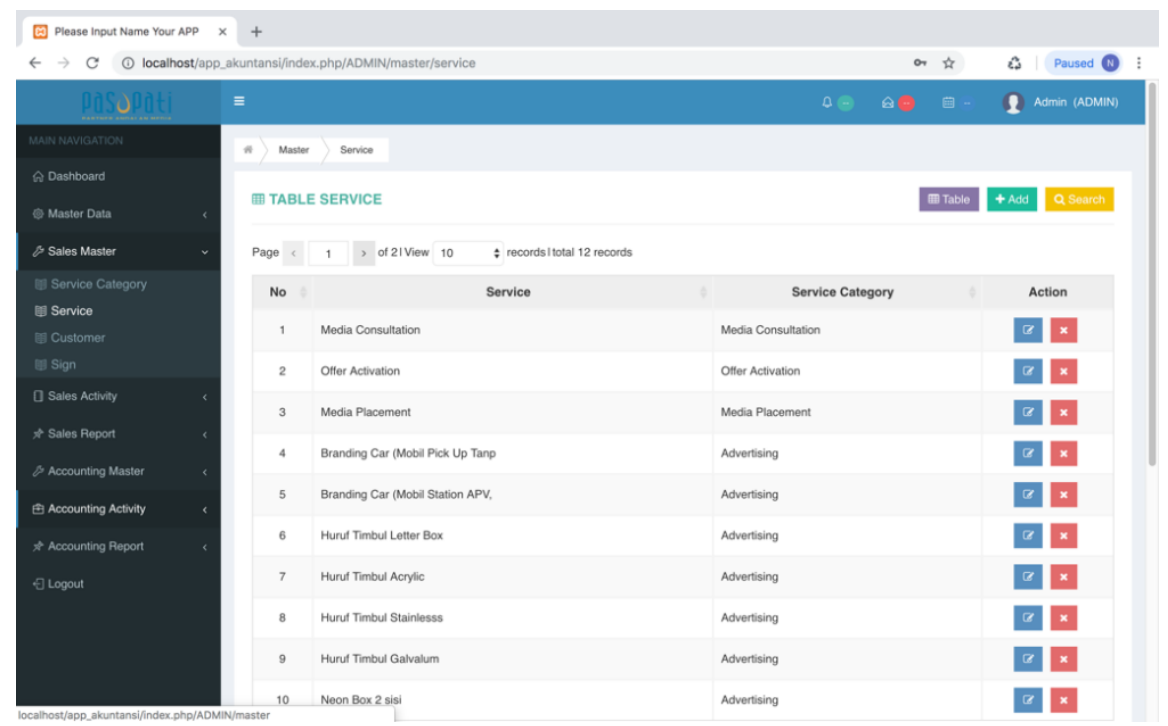

Figure 8. Display Page Service Menu

The above display is a view of the service menu page which presents a page in which there is data that has been inputted by a data service. On this page, users can add data, edit data, delete data and search data. 
8. Display Page Customer Menu

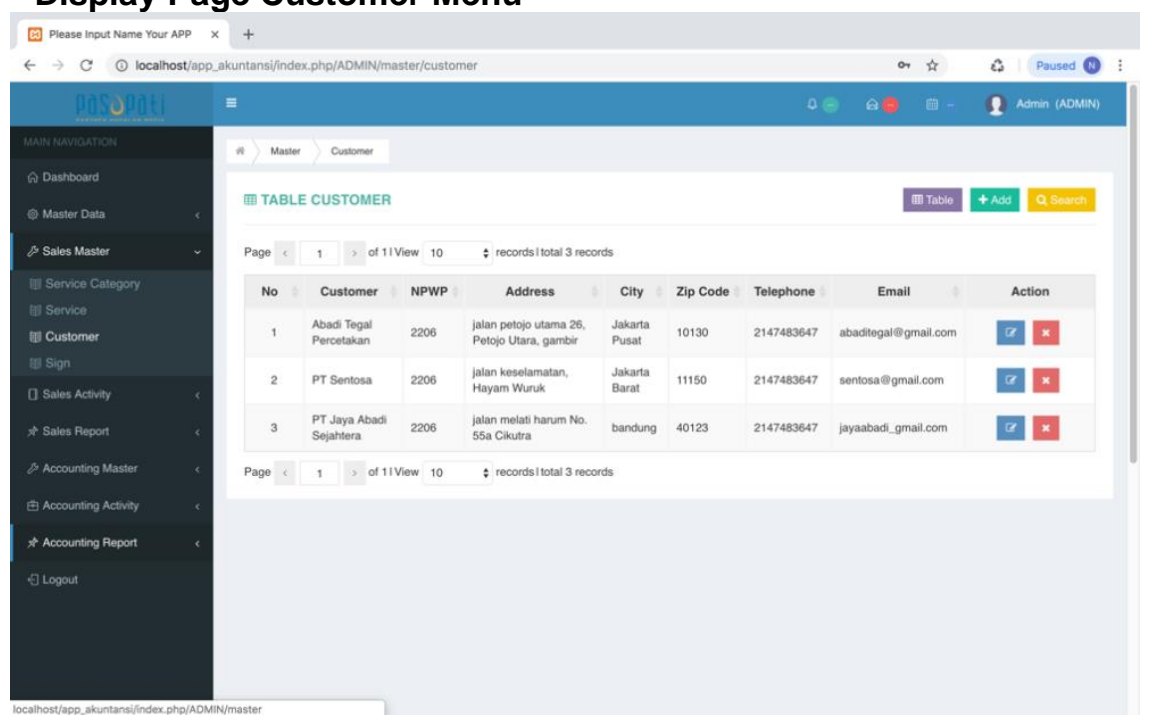

Figure 9. Display Customer Menu

The above display is a view of the customer menu page which presents a page in which there is data that has been inputted by customer data. On this page, users can add data, edit data, delete data and search data.

\section{Display Page Sign Menu}

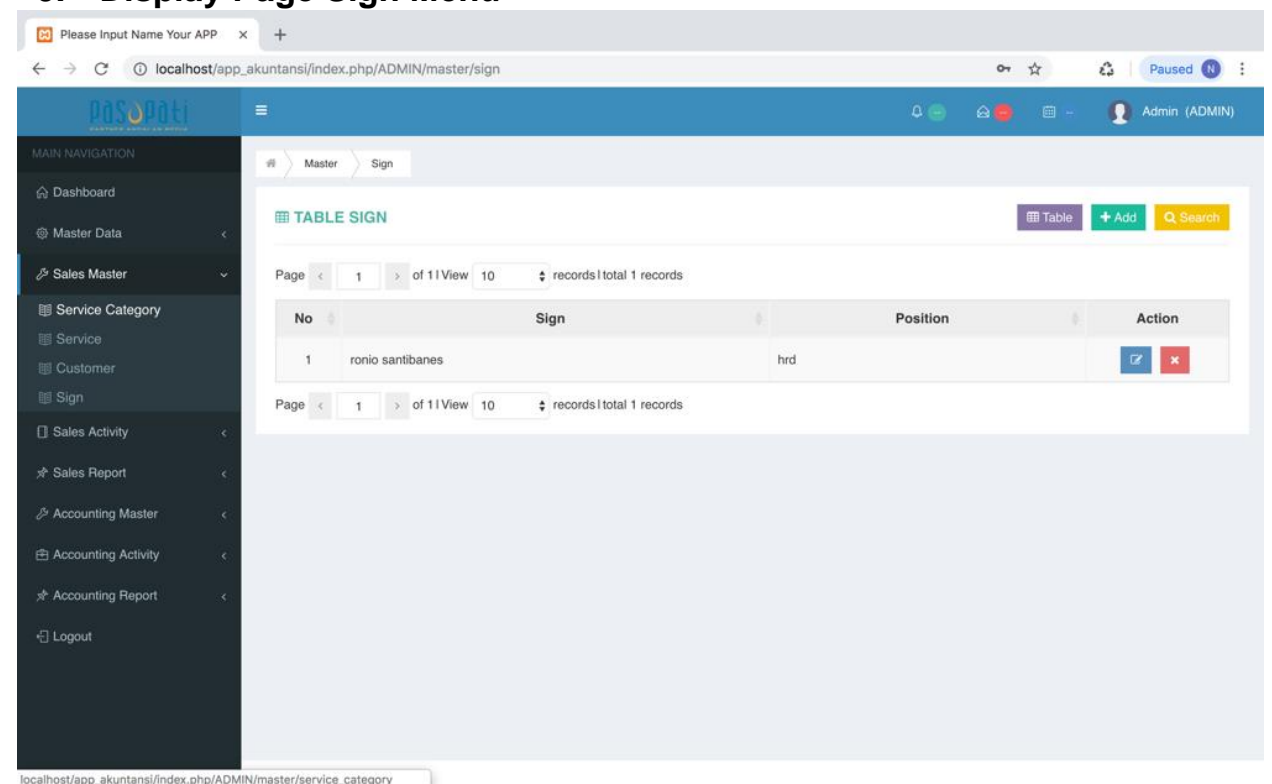

Figure 10. Display Page Sign Menu

The above display is a view of the menu sign page which presents the page where there is data that has been inputted by a data sign. On this page, users can add data, edit data, delete data and search data. 


\section{Display Page Sales Menu}

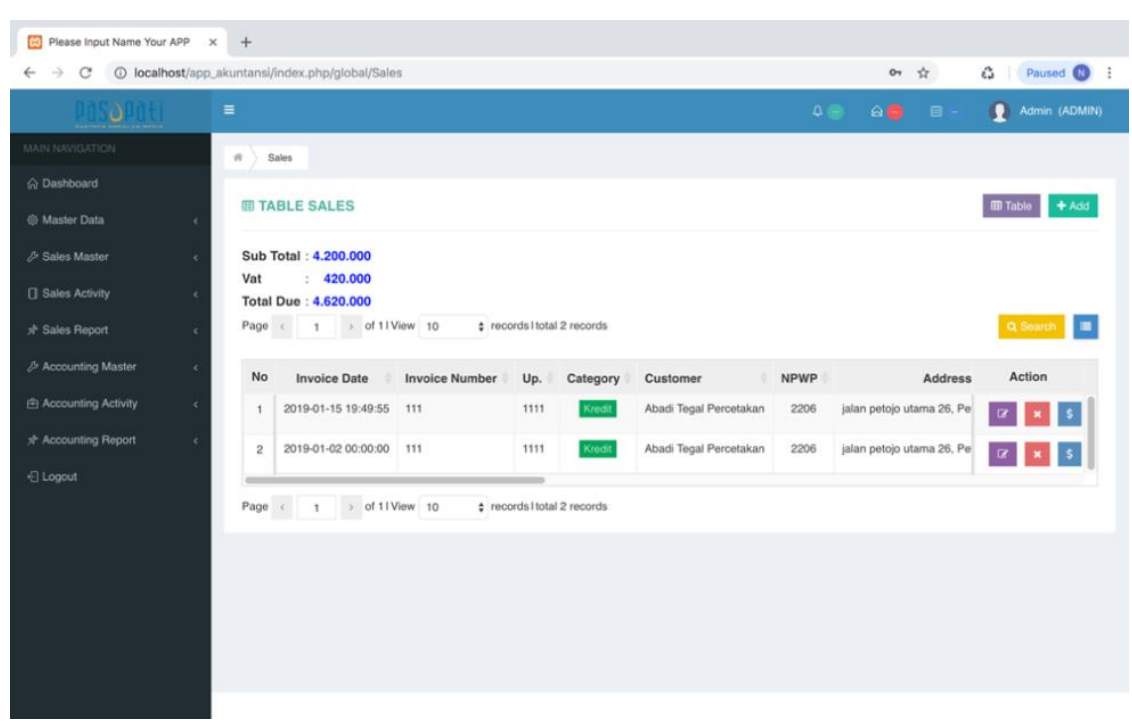

Figure 11. Display Page Sales Menu

The above display is a view of the sales menu page which presents a page in which there is data that has been input sales data. On this page, users can add data, edit data, delete data and search data

\section{Display Page Account Category Menu}

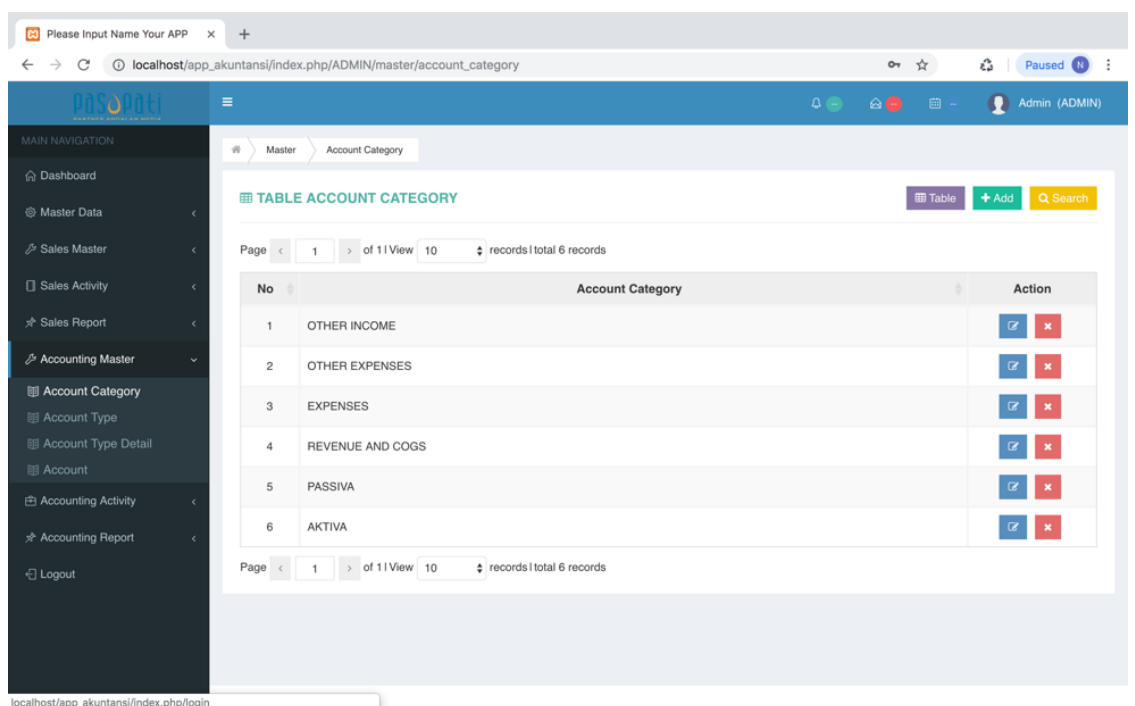

Figure 12. Display Page Account Category Menu

The above display is a view of the Account Category menu page which presents a page in which there is data that has been inputted into Account Category data. On this page, users can add data, edit data, delete data and search data. 


\section{Conclusion}

Based on the discussion that has been described in the previous chapter of the current system in the sales and finance departments at PT Arbunco Wira Pandega, especially in the process of preparing sales reports and financial statements, then researchers can draw conclusions that:

1. The current system has problems in the process of producing sales reports and financial reports such as human error, risk in data storage and more time consuming because the reports generated are not automatic or manual and it results in delays in sales report data from the sales department and financial statement data from the financial department that affects the delay in information to the leadership needed for decision making, and results in unmatched losses such as increased operational costs.

2. Website-based Sales Accounting System is a system that is proposed to provide convenience for PT Arbunco Wira Pandega's sales staff and Accounting Staff in producing accurate and faster reports. Website-based Sales Accounting System is designed by connecting from one process to another so that it can produce reports with a fast time, and of course helps to create effective and efficient performance in providing expected sales and financial reports. In Website-Based Sales Accounting System, there are 5 levels of users provided with different access rights, namely Admin who has full rights to Website-Based Sales Accounting System, Sales Staff who have the right to input sales and payment transactions, Accounting Staff who have the right to input all transactions that occur in the company on the system, Sales Manager who has access rights to view sales reports and Accounting Manager who has access rights to view financial statements. Website-based Sales Accounting System generates reports from the results of transaction data input, including:

1.Sales Report

2. General Ledger

3. Account Receivable Subsidiary Ledger

4.Trial Balance Statement

5. Adjusted Trial Balance Statement

6. Worksheet Statement

7.Financial Statement :

$\checkmark$ Income Statement

$\checkmark$ Balance Sheet Statement 


\section{References}

[1] Ardana, I., \& Hendro Lukman. (2016). Sistem Informasi Akuntansi. Jakarta: Mitra Wacana Media.

[2] Agus Mulyanto. 2009. Sistem Informasi Konsep dan Aplikasi. Pustaka Pelajar.Yogyakarta

[3] Hutahaean, J. (2016). Konsep Sistem Informasi. Yogyakarta: Deepublish.

[4] Kadir, A. (2014). Pengenalan Sistem Informasi. Yogyakarta: Andi

[5] Mulyadi. (2016). Sistem Akuntansi. Yogyakarta: Salemba Empat.

[6] Mulyani, S. (2016). Analisis dan Perancangan Sistem Informasi. Jakarta :AbdiSistematika.

[7] Mulyani, S. (2017). Analisis dan Perancangan Sistem Informasi Manajemen Keuangan Daerah. Jakarta: AbdiSistematika.

[8] Muslihudin, M., \& Oktafianto. (2016). Analisis dan Perancangan Sistem Informasi Menggunakan Model Terstruktur dan UML. Yogyakarta: Andi .

[9] Sujarweni, V. (2015). Sistem Akuntansi. Yogyakarta: Pustaka Baru Press.

[10] Sujarweni, V. (2016). Pengantar Akuntansi. Yogyakarta: Pustaka Baru Press.

[11] Sujarweni, V. (2017). Analisis Laporan Keuangan. Yogyakarta: Pustaka Baru Press.

[12] Nabizadeh, M., \& Seyed, A. O. (2014). Effective Factors on Accounting Information System Alignment; a Step towards Organization Performance Improvement. International Journal of Scientific and Research Publication, 4. Retrieved December 1, 2018, from http://www.ijsrp.org/research-paper-0914.php?rp=P333117

[13] Nasril, \& Yanto Adri Saputra. (2016). Rancang Bangun Sistem Informasi Ujian Online. Jurnal Lentera ICT, 3. Retrieved December 1, 2018, from https://scholar.google.co.id/citations?user=jl-NZnwAAAAJ\&hl=en

[14]Neogy, \& Taposh , K. (2014). Evaluation of Efficiency of Accounting Information System: A Study on Mobile Telecommunication Companies in Bangladesh. Global Disclousure of Economics and Business, 3. Retrieved December 1, 2018, from https://papers.ssrn.com/sol3/papers.cfm?abstract_id=2604404

[15] Nurdin, J. (2018). Pengantar Akuntansi untuk Korporasi. Malang: Empatdua.

[16] Raharjo, B. (2016). Pemrograman Web (HTML, PHP \& MySQL) (3 ed.). Bandung: Modula.

[17] Rahayu, N., \& dkk. (2017). SWOT Analysis Recruitment: PT Indo Taichen Textile Industry. Jurnal Semnasteknomedia, 5. Retrieved December 1, 2018, from https://ojs.amikom.ac.id/index.php/semnasteknomedia/article/view/1643

[18] Rahayu, S., Muhamad Yusup, \& Sinta Puspita Dewi. (2015). Perancangan Aplikasi Absensi Peserta Bimbingan Belajar Berbasis Web Dengan Menggunakan Framework YII. Tangerang. CCIT Journal, 9. Retrieved December 1, 2018, from http://ejournal.raharja.ac.id/index.php/ccit/article/view/157

[19] Romney, M., \& P.J. Steinbart. (2015). Accounting Information Systems (13 ed.). Upper Saddle River, New Jersey: Pearson Education, Inc.

[20]Rusdiana, \& Moch. Irfan. (2014). Sistem Informasi Manajemen. Bandung: Pustaka setia. 